\title{
Cytotoxic and Apoptotic Activities of Rhizopogon roseolus (Corda) Th.Fr. Extracts
}

\author{
Erdi Can Aytar (iD) ${ }^{*}$, Ali Özmen ${ }^{2}$ \\ ${ }^{1}$ Department of Biology, Faculty of Sciences and Arts, Ondokuz Mayıs University, Samsun, Turkey \\ ${ }^{2}$ Department of Biology, Faculty of Sciences and Arts, Adnan Menderes University, Aydın, Turkey
}

\begin{abstract}
Many species of mushrooms have been used since ancient times, especially in Asian countries, as a food supplement and in the medical field due to their different biological activities. Nowadays, especially in Japan, Korea and China, various mushroom extracts have been used as potential additives in chemotherapy and radiation treatments. In this study, anticancer activity and apoptotic effect of Rhizopogon roseolus were investigated. The methanol and water extracts of mushroom were tested against HL- 60 human cancer cell line. Antiproliferative effects of the extracts were evaluated by using MTT method and apoptosis and necrosis ratios of the cells treated with extracts were determined by using Hoechst/Propidium iodide (HO/PI) staining method. According to obtained data, antiprolifarative effect of the methanol extract was higher than water extract and this effect was a concentration depending manner. Both of the extracts were shown higher apoptotic effect than necrotic effect on the HL-60 cell line.
\end{abstract}

\section{ARTICLE HISTORY}

Received: January 15, 2020

Revised: February 25, 2020

Accepted: March 11, 2020

\section{KEYWORDS}

Rhizopogon roseolus,

Mushroom,

Apoptosis,

Cell culture,

HL-60

\section{INTRODUCTION}

Edible mushrooms are widely consumed in many countries because of their low calorie nutrients and specific aromas $[1,2]$. According to data from the United Nations Organization for Food and Agriculture (FAO), worldwide production of mushroom has been increased by about $73 \%$ from 5.91 million tons in 2007 to 10.24 million tons in 2017 [3].

Edible mushrooms are rich in high minerals (potassium, phosphorus, iron), essential amino acids, vitamins (B12 and D) and source of some fiber [1,4,5]. Mushrooms are very attractive in food and pharmaceutical researches due to their bioactive components, such as phenolic compounds, terpenes, steroids and polysaccharides, that have a variety of biological activities. [6,7,8]. The mushroom's compounds possess antifungal activity [9], antigenotoxic [10], antioxidant [5], antiproliferative [11], anticancer [12], antihyperlipidemic [13], antihypertensive, anti-nociceptive and immunostimulanting [14], hypocholesterolemic, antiatherogenic [15], and stress reducing properties [16]. In addition, edible mushroom are good sources of prebiotic substances, especially those containing short chain sugars such as glucose,

CONTACT: Erdi Can Aytar $₫$ erdicanaytar@gmail.com Đ Department of Biology, Faculty of Science and Art, Ondokuz Mayıs University, Samsun, Turkey 
galactose, fructose and $\mathrm{N}$-acetylglucosamine. These include highly bioactive polysaccharides and digestible carbohydrates that stimulate the growth of beneficial microorganisms [17]. These microorganisms serve as probiotics because of their potential to inhibit pathogenic microorganisms in the gastrointestinal tract. In addition, prebiotic compounds have gastrointestinal tolerant in the presence of amylase, gastric juice or bile extract in saliva. Therefore, they afford the ability to activate germs useful for host health. Also, they can be health supportive [18]. In recent years, antidiabetic effects of Agaricus blazei, Coprinus comatus, Cordyceps militaris, Inonotus obliquus, Morchella conica macrofungi have been demonstrated [19].

Strong anti-cancer activities of extracts and bioactive components isolated from different mushrooms have become increasingly understandable [20]. The study received in 1970 was related to pharmacological activities reported that Lentinus edodes and Agaricus bisporus were effective against cancer cells and this work has been an inspiration source for the further discovery of effective molecules [21,22].

The most important ectomycorizal fungi are sulloid fungi.The truffle-like Suillus and Rhizopogon genera are the largest ectomicorizal groups [23]. R. roseolus is a fungi species that establishes an ectomycorizal relationship with the Pinaceae family [24]. The species was first described in Europe in the 19th century (25). This mushroom has been involved in numerous research programs targeting afforestation. It is also an exemplary species for morphology, physiology and ecology in ectomycorrhizal relationships [26]. A literature review showed that several biological activity of $R$. roseolus were identified. Akata et al., investigated antioxidant properties of $R$. roseolus. The high antioxidant activity at low concentration of extract was shown [16]. Yamaç et al., studied antimicrobial activities of ethanol and dichloromethane $R$. roseolus extracts. It was found, the ethanol and dichloramethane extracts have a low antimicrobial effect against Escherichia coli (ATCC 25922), Pseudomonas aeruginosa (ATCC 27853), Staphylococcus aureus (ATCC 25923); chloroform extract against Pseudomonas aeruginosa (ATCC 27853) and Staphylococcus aureus (ATCC 25923) [27].

Cancer was one of the leading cause of global deaths in 2018, responsible for 18.1 million new cases and 9.6 million cancer deaths worldwide [28]. The incidence and mortality of cancer have been increasing rapidly for decades due to environmental violations and socioeconomic developments deteriorating [29]. The survival rate of cancer patients has been extended due to recent advances in the diagnosis and treatment of diseases [30].

The definition of traditional medicine according to World Health Organization; plant, animal and mineral based health practices are described as studies aimed at treating or maintaining health [31]. Metabolic syndromes affect people of all age groups. Natural compounds are noteworthy because chemical compounds are perceived to be incompatible with the human body. Depending on the stage of cancer progression, the treatments include surgical operation, radiotherapy, chemotherapy, and biological therapy. Existing anti-cancer chemotherapeutic agents are formulated with toxic solvents and this situation results in various side effects and complications in the clinical management of various forms of cancer. When administered, these drugs cause significant damage to non-cancerous tissues. This usually leads to serious and unwanted side effects, such as kidney toxicity, bone marrow suppression, hair loss (alopecia) and grease of intestinal epithelial cells. Therefore, the search for new and natural anticancer bioactive compounds has been become of great interest [32]. In this study, the antiproliferative and apoptotic effects of methanolic and water extracts of mushrooms $R$. roseolus on the HL-60 cancer cell line were investigated firstly. 


\section{MATERIAL and METHODS}

\subsection{Mushroom Material}

$R$. roseolus was collected from Bozkır district of Konya in 2012 and was identified by Prof. Dr. Hasan Hüseyin Doğan from Selçuk University.

\subsection{Preparation of the Extract}

$R$. roseolus powder was extracted by ten fold methanol and water for one week at room temperature and dark environment. After filtration through a Whatman filter paper, the solvent was removed with a rotary evoporator at 70 mbar at $45^{\circ} \mathrm{C}$ to give a solid extract. Dissolved extracts were centrifuged at $+4^{\circ} \mathrm{C}$ in a refrigerated centrifuge for 5 minutes at $12,000 \mathrm{rpm}$. The resulting supernatants were transferred to another tube for cytotoxic evaluation and the remaining pellets were stored at $-80^{\circ} \mathrm{C}$.

\subsection{Cell Culture}

The HL-60 cell line was obtained from American Type Culture Collection (ATCC), and it was been grown in Dulbecco's Modified Eagle's Medium (DMEM) (invitrogen). The culture medium additions [fetal calf serum, L-glutamine, streptomycin-penicillin, non-essential amino acids (GIBCO), Hoechst 33258, and propidium iodide (Sigma-Aldrich Co.)] were used to determine apoptotic effect.

\subsubsection{Antiproliferative Activity of the Extract}

Cells were grown in culture flask at a range of 10,000-100,000 cells per ml. Mushroom extracts were applied at increasing concentrations $(1,5,10,20$ and $40 \mathrm{mg} / \mathrm{mL})$ for 24,48 and 72 hours. Viable cells in the control and application groups were determined by MTT [3- $(4,5-$ dimethyl thiazol-2-yl) -2,5-diphenyl tetrazolium bromide] staining method [33]. The solution was measured by spectrophotometer (Thermo/LabSystems 352 Multiskan MS Microplate Reader) at $590 \mathrm{~nm}$.

$$
\left[\left(\mathrm{C}_{72 \mathrm{~h}+\text { extract }}-\mathrm{C}_{24 \mathrm{~h}+\text { extract }}\right) /\left(\mathrm{C}_{72 \mathrm{~h} \text { - control }}-\mathrm{C}_{24 \mathrm{~h} \text { - control }}\right)\right] \times 100=\% \text { dividing cell viabilty }
$$

$\mathrm{C}_{72 \mathrm{~h}+\text { extract: }}$ Live cell measurement 72 hours after manipulation

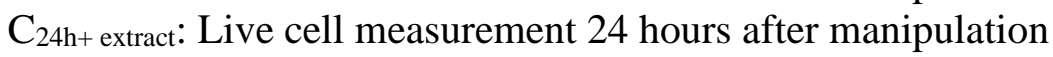

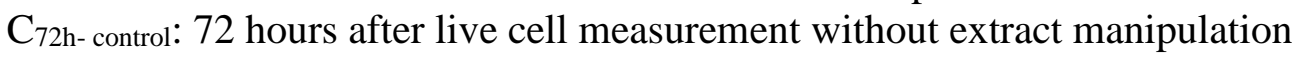

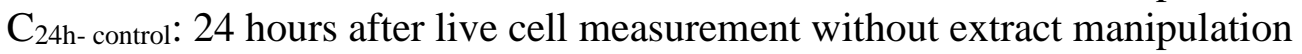

All experiments were performed with three replications.

\subsection{Apoptosis and Necrosis Effects of the Extracts}

For determination of the apoptotic and necrotic effects the HL-60 cells were grown at low density in culture flasks (DMEM). These cells were stained with HO/PI (Hoechst 33258/Propidium Iodide) method and extracts showing apoptotic and necrotic effects were determined [34,35]. These cells were investigated and were counted under microscope (Leica). Graphics are presented in comparison with the control group. Apoptosis and necrosis rates were expressed as \% increase (\% control) in the application groups compared to the number in the control group.

\subsection{Statistical Evaluation}

Differences between control and application groups were transferred to graphics containing standard errors with GraphPad 4.0 analysis program. The living cells in the control group and the living cells in the application groups are shown in separate columns. Standard errors in the data obtained in three replicates were calculated. 


\section{RESULTS and DISCUSSION}

\subsection{Antiproliferative Activity of the Extracts}

The experimental data of antiproliferative activity of $R$. roseolus extracts on HL-60 cell line by MTT method are shown in Figure1. It was found, that the methanol extract in the range of $1-40 \mathrm{mg} / \mathrm{mL}$ have a better antiproliferative activity of HL-60 cell line than the water extract of $R$. roseolus. In addition, the lowest concentration of methanol extract $1 \mathrm{mg} / \mathrm{mL}$ of methanol extract on HL-60 cell line which is the lowest concentration of caused less than $50 \%$ of the antiproliferative effect was found to be with high statistical significance. Furthermore, the value at which the methanol extract kills all the cells is $5 \mathrm{mg} / \mathrm{mL}$, while the water extract is approximately $16 \mathrm{mg} / \mathrm{mL}$.
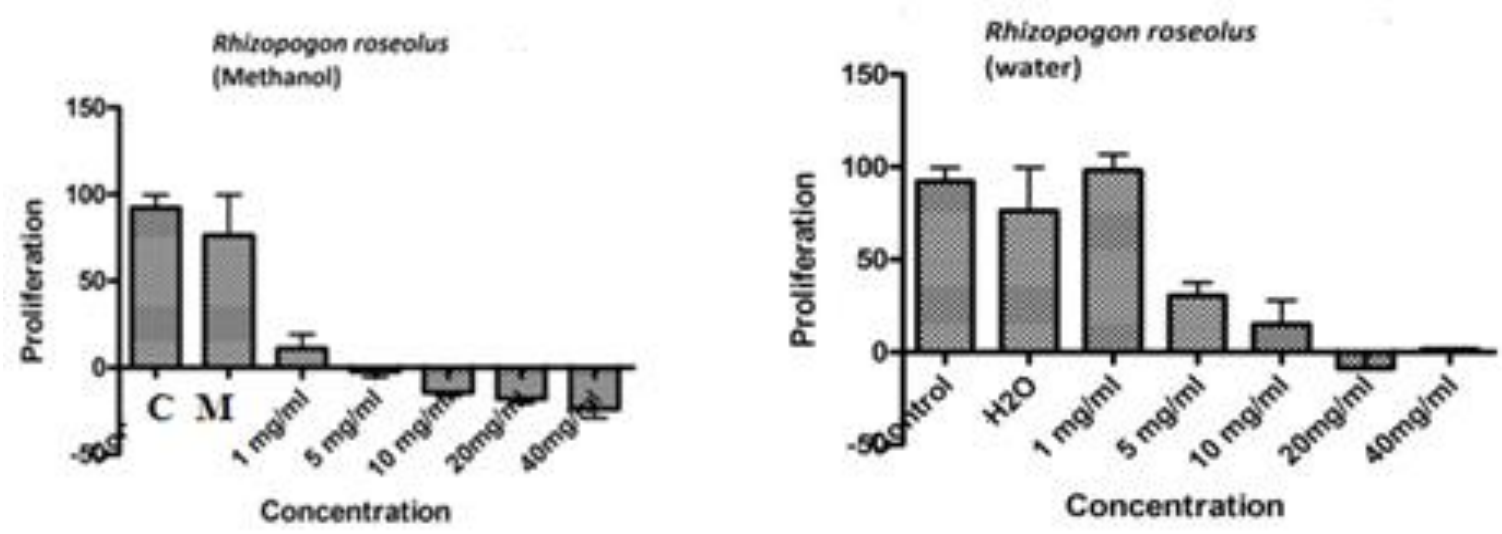

Figure 1. Influence of $R$. roseolus extract on the proliferation of HL-60 cell line (C: Control, M: Methanol)

\subsection{Apoptotic and Necrotic Effects of the Extracts}

As a result of the counts and analyzes, the findings were shown in Figure 2 and Figure 3.

Rhizopogon roseolus methanol (Apoptosis)

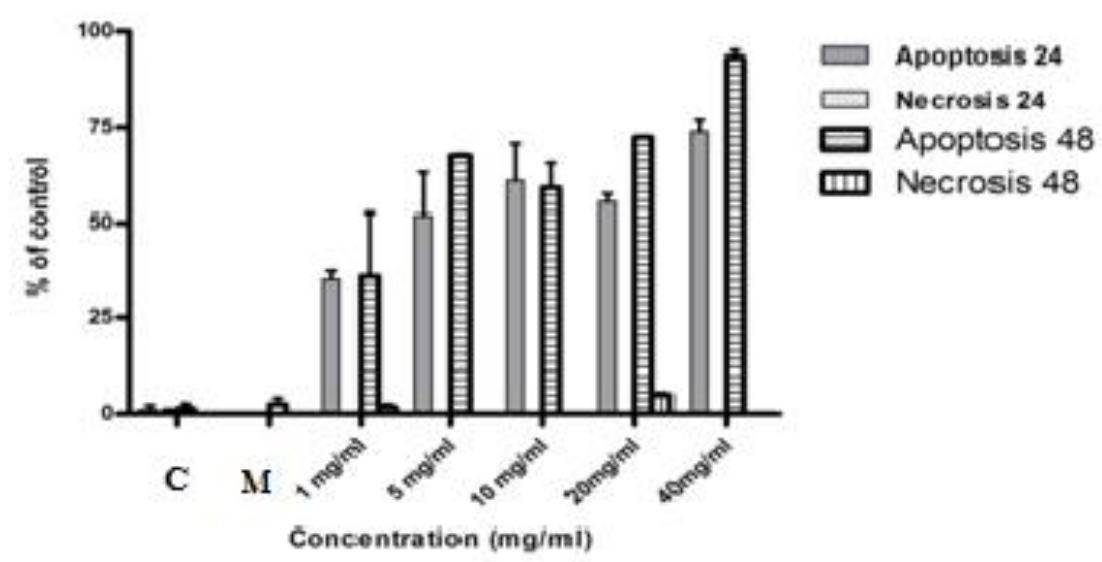

Figure 2. Percentages of the apoptosis and necrosis of the cells treated with the methanol extract during 24 and 48 hours (C: Control, M: Methanol).

Approximately 50\% apoptotic effect was observed with 24 hours incubation of R.roseolus $5 \mathrm{mg} / \mathrm{mL}$ methanol extract on HL-60 cells. Moreover, this rate increased to approximately $75 \%$ with 48 hours incubation. Besides this apoptotic effect, the necrotic effect has hardly been observed. As the concentration of the extract increased, more apoptotic activity was observed. 
In particular, the extract of $40 \mathrm{mg} / \mathrm{mL}$ concentration was found with 48 hours incubation $100 \%$ apoptotic activity.

Rhizopogon roseolus water (Apoptosis)

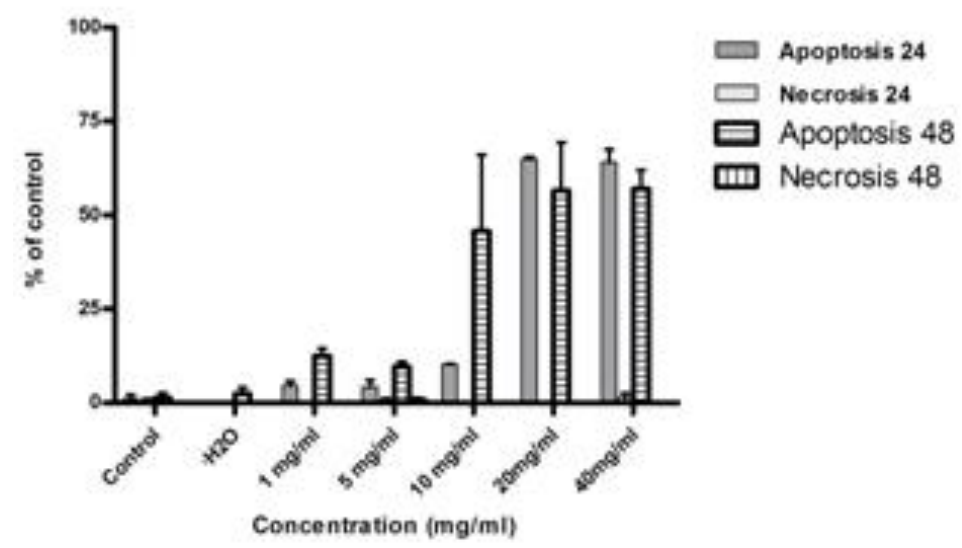

Figure 3. Percentages of the apoptosis and necrosis of the cells treated with the water extract during 24 and 48 hours

The water extract of $R$. roseolus increased in parallel with the increase in apopotic effect concentration. Treatment with water extract inhibited the growth of HL-60 cell in a time dependent manner and the concentration of between $20-40 \mathrm{mg} / \mathrm{mL}$ against HL-60 was found with 48 hours incubation the best apoptotic activity (approximately 70\%), but the necrotic effect has hardly been observed.

Reishi mushroom is an important medicinal mushroom in traditional Chinese medicine more than two thousand years. The most widely used species of Reishi mushroom is Ganoderma lucidum, which is currently commercially grown. G. lucidum (F.) Karst. (Polyporaceae) is used in the prevention and treatment of various diseases such as hypertension, tumorogenic diseases and immunological disorders in China, Japan and other Eastern countries. Although the fruit body of $G$. lucidum has been used as a traditional herbal remedy since ancient times, the spores have been started to use in the late 20th century [36-40]. In the study of Hu et al., demonstrated that cytotoxic activity of G. lucidum alcohol extract on the MCF-7 cancer cell line. After 48 hours, at $500 \mu \mathrm{g} / \mathrm{mL}$ concentration, this alcohol extract caused about $70 \%$ inhibition of cell growth compared to the control [41]. In another study, Kim et al. [42] investigated the cytotoxicity of G. lucidum extract on HL-60 cells by conventional tetrazoliumbased colorimetric cell proliferation assay. After 48 hours incubation, they reported that 210 $\mu \mathrm{g} / \mathrm{mL}$ required to kill $50 \%$ of the cells $\left(\mathrm{IC}_{50}\right.$ ) [42].

Some fungi belonging to the genus Suillus have significant medical activities $[43,44]$. Santos et al., investigated that antiproliferative activity of $S$. luteus methanol extract on colon cancer cell line by MTT method. The most effective amount was found to be $\mathrm{IC}_{50}=17.75 \pm 1.6$ $\mu \mathrm{g} / \mathrm{mL}$ on HCT-15. They also investigated its apoptotic effect on lung cancer cell line p-H2A.X by TUNEL method. They found the $\mathrm{IC}_{50}$ values in 24 and 48 hours as $1.2 \pm 0.4$ and $1.2 \pm 0.06$ $\mathrm{mg} / \mathrm{mL}$, respectively [45]. Vaz et al., also concluded cytotoxic activity of $S$. collinitus on ASG

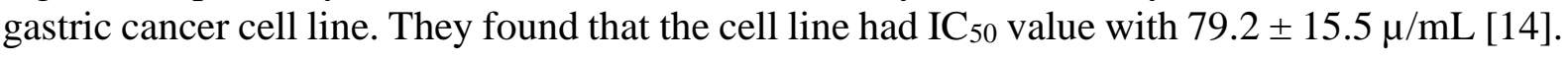

Hericium erinaceus is a fungus consumed as food. In recent years, novel compounds with multifaceted bioactivities, such as isoindolines and diterpenoids, have been discovered in this fungus [46-49]. In previous studies, Chen et al., [50] reported that cytotoxic activity of diterponoid isolated $H$. erinaceus on HL-60 cancer cell line was determined. They found the $\mathrm{IC}_{50}$ on the HL-60 cell line to be $8.9 \mu / \mathrm{mL}$ [50]. Lavi et al., [51] found that antiproliferative activity of Pleurotus ostreatus crude extracts on HT-29 colon cancer cells. According to these 
results, the $\mathrm{IC}_{50}$ value of ethyl acetate extract was found as $0.05 \mathrm{mg} / \mathrm{mL}$ and $\mathrm{IC}_{50}$ value of $\mathrm{n}$ hexane extract was found as $0.2 \mathrm{mg} / \mathrm{mL}$ [51]. The different fungi studied under the research have differences both at the cell line level and on excitation of apoptosis mechanisms. These differences are linked to the active ingredients contain.

\section{CONCLUSION}

$R$. roseolus samples have high cytotoxic and apoptotic activity at low concentration of methanol and water extracts. In conclusion, our studies proved that $R$. roseolus extracts of the HL-60 cells in a dose-dependent manner as well as apoptosis. Cytotoxic activity studies of $R$. roseolus have not been encounter in the literature. Further studies can be conducted on $R$. roseolus, especially methanol extract as a potential anticancer agent. It is predicted that these new findings added to the literature will be effective in further studies.

\section{Acknowledgements}

We thank to Prof. Dr. Hasan Hüseyin Doğan for the mushroom identification.

\section{Declaration of Conflicting Interests and Ethics}

The authors declare no conflict of interest. This research study complies with research publishing ethics. The scientific and legal responsibility for manuscripts published in IJSM belongs to the author(s).

\section{Orcid}

\section{Erdi Can AYTAR (iD https://orcid.org/0000-0001-6045-0183}

\section{REFERENCES}

[1]. Feeney, M.J., Dwyer, J., Hasler-Lewis, C.M., Milner, J.A., Noakes, M., Rowe, S., Wach, M., et al. (2014). Mushrooms and Health Summit Proceedings. J. Nutr., 144(7), 11281136.

[2]. Kalač, P. (2013). Chemical Composition and Nutritional Value of European Species of Wild Growing Mushrooms: A Review. Food Chem, 113, 9-16.

[3]. Reisa, G.C.L., Custodioa, F.B., Botelhob, B.G., Guidic, L.R., Gloriaa, M.B.A. (2020). Investigation of Biologically Active Amines in Some Selected Edible Mushrooms. J. Food Compos. Anal., 86, 103375.

[4]. Manninen, H., Rotola-Pukkila, M., Aisala, H., Hopia, A., Laaksonen, T. (2018). Free Amino Acids and 5'-Nucleotides in Finnish Forest Mushrooms. Food Chem., 247, 23-28.

[5]. Roupas, P., Keogh, J., Noakes, M., Margetts, C., Taylor, P. (2012). The Role of Edible Mushrooms in Health: Evaluation of The Evidence. J. Funct. Foods, 4, 687-709.

[6]. Mariga, A.M., Yang, W.J., Mugambi, D.K., Pei, F., Zhao, L., Shao, Y.N., Hu, Q. (2014). Antiproliferative and Immuno Stimulatory Activity of a Protein from Pleurotus eryngii. $J$ Sci Food Agr., 94, 3152-3162.

[7]. Sheu, F., Chien, P.J., Wang, H.K., Chang, H.H., Shyu, Y.T. (2007). New Protein PCiP from Edible Golden Oyster Mushroom (Pleurotus citrinopileatus) Activating Murine Macrophages and Splenocytes. J Sci Food Agr., 87, 1550-1558.

[8]. Shang, H.M., Song, H., Xing, Y.L., Niu, S.L., Ding, G.D., Jiang, Y.Y., Liang, F. (2015). Effects of Dietary Fermentation Concentrate of Hericium caput-medusae (Bull.:Fr.) Pers. on Growth Performance, Digestibility, and Intestinal Microbiology and Morphology in Broiler Chickens. J Sci Food Agr., 96, 215-222.

[9]. Osaki, K., Suyama, S., Sakuno, E., Ushijima, S., Nagasawa, E., Maekawa, N., Ishihara, A. (2019). Antifungal Activity of The Volatile Compound Isovelleral Produced by Ectomycorrhizal Russula Fungi Against Plant-Pathogenic Fungi. J. Gen. Plant Pathol., 85, 428-435. 
[10]. Wang, J.C., Hu, S.H., Liang, Z.C., Lee, M.Y. (2005). Antigenotoxicity of Extracts from Pleurotus citrinopileatus. J. Sci. Food Agr., 85, 770-778.

[11]. Zhou, J., Chen, Y., Xin, M., Luo, Q., Gu, J., Zhao, M., Xu, X., et al. (2013). Structure Analysis and Antimutagenic Activity of a Novel Salt-Soluble Polysaccharide from Auricularia polytricha. J Sci Food Agr., 93, 3225-3230.

[12]. Kim, S.H., Jakhar, R., Kang, S.C. (2015). Apoptotic Properties of Polysaccharide Isolated from Fruiting Bodies of Medicinal Mushroom Fomes fomentarius in Human Lung Carcinoma Cell Line. Saudi J. Biol. Sci., 22, 484-490.

[13]. Opletal, L., Jahodar, L., Chobot, V., Zdansky, P., Lukes, J., Bratova, M., Solichova, D. et al. (1997). Evidence for The Antihyperlipidemic Activity of Edible Fungus Pleurotus ostreatu. Brit J Biomed Sci., 54, 240-243.

[14]. Vaz, J.A., Barros, L., Martins, A., Santos-Buelga, C., Vasconcelos, M., Ferreira, I.C. (2011). Chemical Composition of Wild Edible Mushrooms and Antioxidant Properties of Their Water Soluble Polysaccharidic and Ethanolic Fractions. Food Chemistry, 126, 610616.

[15]. Han, E.H., Hwang, Y.P., Kim, H.G., Choi, J.H., Im, J.H., Yang, J.H., Lee, H.U. et al. (2011). Inhibitory Effect of Pleurotus eryngii Extracts on the Activities of Allergic Mediators in Antigen-Stimulated Mast Cells. Food Chem. Toxicol., 27, 1199-1128.

[16]. Akata, I., Ergonul, B., Kalyoncu, F. (2012). Chemical Compositions and Antioxidant Activities of 16 Wild Edible Mushroom Species Grown in Anatolia. Int. J. Pharmacol., $8,134-138$.

[17]. Patel, S., Goya, A. (2011). Functional Oligosaccharides: Production, Properties and Applications. World J Microb. Biot., 27, 1119-1128.

[18]. Chowdhury, S., Shreya, D., Bhattacharjee, D., Saha, P.K., Mukherjee, S., Bhattacharyya, B.K. (2015). Prebiotics-clinical relevance. Indian J. Nat. Prod., 6, 91-97.

[19]. Stojkovic, D., Smiljkovic, M., Ciric, A., Glamoclija, J., Van Griensven, L., Ferreira, I.C., Sokovic, M. (2019). An Insight into Antidiabetic Properties of Six Medicinal and Edible Mushrooms: Inhibition of $\alpha$-amylase and $\alpha$-glucosidase Linked to Type-2 Diabetes. $S$. Afr. J. Bot., 120,100-103.

[20]. Jiang, S., Wang, S., Sun, Y., Zhang, Q. (2014). Medicinal Properties of Hericium erinaceus and Its Potential to Formulate Novel Mushroom-Based Pharmaceuticals. Appl. Microbiol. Biotechnol., 98(18), 7661-7670.

[21]. Chihara G, Hamuro J, Maeda Y, Arai Y, Fukuoka F (1970). Fractionation and Purification of The Polysaccharides with Marked Antitumor Activity, Especially Lentinan, from Lentinus edodes (Berk.) Sing. an Edible Mushroom. Canc. Res., 30(11), 2776-2781.

[22]. Vogel, F.S., Kemper, L.A., McGarry, S.J., Graham, D.G. (1975). Cytostatic, Cytocidal and Potential Antitumor Properties of a Class of Quinoid Compounds, Initiators of the Dormant State in the Spores of Agaricus bisporus. Am. J. Pathol., 78(1), 33-48.

[23]. Pietras, M. (2019). First Record of North American Fungus Rhizopogon pseudoroseolus in Australia and Prediction of Its Occurrence Based on Climatic Niche and Symbiotic Partner Preferences. Mycorrhiza, 29, 397-401.

[24]. Molina, R., Trape, J.M. (1994). Biology of The Ectomycorrhizal Genus, Rhizopogon. I. Host associations, Host-Specificity and Pure Culture Syntheses. New Phytol., 126, 653675.

[25]. Smith, A.H., Zeller, S.M. (1966). A Preliminary Account of The North American Species of Rhizopogon. Memoirs of the New York Botanical Garden, 14, 178

[26]. Miranda, F.E., Majada, J., Casares, A. (2017). Efficacy of Propidium Iodide and FUN-1 Stains for Assessing Viability in Basidiospores of Rhizopogon roseolus. Mycologia, 109(2), 350-358. 
[27]. Yamaç, M., Bilgili, F. (2006). Antimicrobial Activities of Fruit Bodies and/or Mycelial Cultures of Some Mushroom Isolates. Pharm. Biol., 44(9), 660-667.

[28]. Bray, F., Ferlay, J., Soerjomataram, I., Siegel, R.L., Torre, L.A., Jemal, A. (2018). GLOBOCAN estimates of incidence and mortality worldwide for 36 cancers in 185 countries. CA Cancer J. Clin., 68, 394-424.

[29]. Ferlay, J., Colombet, M., Soerjomataram, I., Mathers, C., Parkin, D.M., Pineros, M., Znaor, A. et al. (2019). Estimating the Global Cancer Incidence and Mortality in 2018: GLOBOCAN Sources and Methods. Int. J. Cancer, 144, 1941-1953.

[30]. Cannon, C.A., Watson, L.K., Roth, M.T., LaVergne, S. (2014). Assessing the Learning Needs of Oncology Nurses. Clin. J. Oncol. Nurs., 18(5), 577-580.

[31]. Çevik, A.B., Akinci, A.B., Bağlama, S.S. (2019). The Use of Complementary and Alternative Medicine Among Lymphoma and Cancer Patients with a Solid Tumor: Oncology Clinics at Northern and Southern Turkey. Complement. Ther. Med., 47, 102173.

[32]. Asatiani, M.D., Sharvit, L., Barseghyan, G.S., Chan, J.S.L., Elisashvili, V., Wasser,S.P. (2018). Cytotoxic Activity of Medicinal Mushroom Extracts on Human Cancer Cells. SF Biotechnol Bioeng., 1(1), 1006.

[33]. Vrba, J., Dolezel, P., Vicar, J., Modriansky, M., Ulrichova, J. (2008) Chelerythrine and Dihydrochelerythrine Induce G1 Phase Arrest and Bimodal Cell Death in Human Leukemia HL-60 Cells. Toxicol in Vitro, 22, 1008-1017.

[34]. Grusch, M., Polgar, D., Gfatter, S., Leuhuber, K., Huettenbrenner, S., Leisser, C., Fuhrmann, G. et al. (2002). Maintenance of ATP Favours Apoptosis Over Necrosis Triggered by Benzamide Riboside. Cell Death Differ., 9, 169-178.

[35]. Huettenbrenner, S., Maier, S., Leisser, C., Polgar, D., Strasser, S., Grusch, M., Krupiltza, G. (2003). The Evolution of Cell Death Programs as Prerequisites of Multicellularity. Mutat. Res., 543(3), 235-49.

[36]. Russell, R., Paterson, M. (2006). Ganoderma-a Therapeutic Fungal Biofactory. Phytochemistry, 67, 1985-2001.

[37]. Liu, X., Yuan, J.P., Chung, C.K., Chen, X.J. (2002). Antitumor Activity of The Sporoderm-Broken Germinating Spores of Ganoderma lucidum. Cancer Lett., 182,155161.

[38]. Min, B.S., Gao, J.J., Nakamura, N., Hattori, M. (2000). Triterpenes from The Spores of Ganoderma Lucidum and Their Cytotoxicity against Meth-A and LLC Tumor Cells. Chem. Pharm. Bull., 48, 1026-1033.

[39]. Xie, Y.Z., Li, S.Z., Yee, A., La Pierre, D.P., Deng, Z.Q. Lee D.Y.,Wu, Q.P. et al. (2006). Ganoderma Lucidum Inhibits Tumour Cell Proliferation and Induces Tumour Cell Death. Enzyme Microb Tech., 40, 177-185.

[40]. Huie, C.W., Di, X. (2004). Chromatographic and Electrophoretic Methods for Lingzhi Pharmacologically Active Components. J. Chromatogr. B., 812, 241-257.

[41]. Hu, H., Shikahn, N., Yang, X., Lee, Y.S., Kang, K.S. (2002). Ganoderma lucidum Extract Induc Cell Cycle Arrest and Apoptosis in MCF-7 Human Breast Cancer Cell. Int. J. Cancer, 102, 250-253.

[42]. Kim, K.C., Kim, J.S., Son, J.K.,Kim, I.G. (2007). Enhanced Induction of Mitochondrial Damage and Apoptosis in Human Leukemia HL-60 cells by the Ganoderma lucidum and Duchesnea chrysantha Extracts. Cancer Lett., 246, 210-217

[43]. Liu, F., Luo, K., Yu, Z., Co, N., Wu, S., Wu, P., Fung, K. et al. (2009). Suillin from the Mushroom Suillus placidus as Potent Apoptosis Inducer in Human Hepatoma HepG2 Cells. Chem-Biol Interact., 181,168-174. 
[44]. Vaz, J.A., Ferreira, I.C., Tavares, C., Almedia, G.M., Martins, A., Vesconcelos, M. (2012). Suillus collinitus Methanolic Extract Increases P53 Expression and Causes Cell Cycle Arrest and Apoptosis in a Breast Cancer Cell Line. Food Chem., 135, 596-602.

[45]. Santos, T., Tavares, C., Sousa, D., Vaz, J.A., Calhelha, R.C., Martins, A., Almeida, G.M., et al. (2013). Suillus luteus Methanolic Extract Inhibits Cell Growth and Proliferation of a Colon Cancer Cell Line. Food Res. Int., 53, 476-481.

[46]. Friedman, M. (2015). Chemistry, Nutrition, and Health-Promoting Properties of Hericium erinaceus (lion's mane) Mushroom Fruiting Bodies and Mycelia and Their Bioactive Compounds. J Agr Food Chem., 63, 7108-7123.

[47]. Wu, J., Tokunaga, T., Kondo, M., Ishigami, K., Tokuyama, S., Suziki, T., Choi, J.H. et al. (2015). Erinaceolactones A to C, from the Culture Broth of Hericium erinaceus. $J$. Nat. Prod, 78, 155-158.

[48]. Chen, L., Li, Z.H., Yao, Y., Peng, L., Huang, R. Feng, T., Liu, J.K. (2017). Isoindolinonecontaining Meroterpenoids with $\alpha$-glucosidase Inhibitory Activity from Mushroom Hericium caput-medusae. Fitoterapia, 122, 107-114.

[49]. Zhang, Z., Liu, R.N., Tang, J., Zhang, Y., Yang, Y., Shang, X.D. (2015). A new diterpene from the fungal mycelia of Hericium erinaceus. Phytochem. Lett., 11, 151-156.

[50]. Chen, L., Yao, J.N., Chen, H.P., Zhao, Z.Z., Li, Z.H., Feng, T., Liu, J.K. (2018). Hericinoids A-C, Cyathane Diterpenoids From Culture of Mushroom. Hericium erinaceus. Phytochem. Lett., 27, 94-100.

[51]. Lavi, I., Friesem, D., Geresh, S., Hadar, Y., Schwartz, B. (2006). An Aqueous Polysaccharide Extract from the Edible Mushroom Pleurotus ostreatus Induces AntiProliferative and Pro-Apoptotic Effects on HT-29 Colon Cancer Cells. Cancer Lett., 244, 61-70. 